\title{
Case study of Narmada main canal based drinking water supply project: issues and challenges
}

\author{
S. M. Yadav \& K. A. Chauhan \\ Department of Civil Engineering, S.V.NIT, Surat, Gujarat, India
}

\begin{abstract}
A concrete gravity dam, 1210 meters in length and with a maximum height of 163 meters above the deepest foundation level, is under construction across River Narmada. The dam will be the third highest concrete dam (163 meters) in India. In terms of the volume of concrete involved for gravity dams, this dam will rank as the second largest in the world with an aggregate volume of 6.82 million cu.m. The first is Grand Coule Dam in USA with a total volume of 8.0 million cu.m. This dam with its spillway discharging capacity of 87,000 cumecs (30.70 lac), will be the third in the world, Gazenba (1.13 lac cumecs) in China and Tucurri (1.0 lac cumecs) in Brazil being the first two. The gross storage capacity of the reservoir is $0.95 \mathrm{M}$. ha.m. (7.7 MAF) while live storage capacity is 0.58 M.ha.m. (4.75 MAF). The dead storage capacity below minimum draw down level is $0.37 \mathrm{M}$. ha. m. (2.97 MAF). The construction of the dam up to 121.6 meter is over and construction of the $456 \mathrm{~km}$ long main canal is almost completed. The state of Gujarat can be divided into four parts as far as available water resources are concerned (i) South and Central Gujarat, (ii) Saurashtara, (iii) North Gujarat, (iv) Kachchha. Out of the total water resources of the state (ground as well as surface water) the areas of Kachchh, North Gujarat and Saurashtara have 2\%, 11\% and $16 \%$ water resources respectively which covers a $58 \%$ area of the state. These areas are subjected to drought happening once in a five year frequency. These areas are one of the most water stressed area of the state as well as country. The mass migration tendencies seasonal as well as permanent towards Central and South Gujarat are observed regularly due to shortage of water, food and fodder. The main canal of Narmada dam has become a new source of water for this region. The present paper mainly focuses on the issues related to sustainable usage of canal water for drinking
\end{abstract}


purposes. The Sardar Sarovar Canal based drinking water supply project is the biggest drinking water supply project in the world. It will cover Saurashtra, Kachchh and parts of North Gujarat. The progress so far is $68 \%$ of villages are covered against proposed coverage. To make this project more sustainable it has to cope with challenges like reliability of supply, adequacy of supply, unequal inter village distribution, unequal intra village distribution, inefficiency in operation and maintenance, water charges, recovery of charges, neglected local source of water, lack of systematic disposal of used water, village level management and neglected local water sources. The paper discuss the above issues with probable remedial measures to make the scheme sustainable.

Keywords: water resources, Narmada main canal, drinking water, issues, sustainable development.

\section{Introduction}

Gujarat is one of the states of India. The state of Gujarat can be divided into four parts as far as available water resources are concerned (i) South and Central Gujarat, (ii) Saurashtara, (iii) North Gujarat, (iv) Kachchha. Out of the total water resources of the state (ground as well as surface water) the areas of Kachchh, North Gujarat and Saurashtara have 2\%, 11\% and 16\% water resources respectively which cover a $58 \%$ area of the state. These areas are subjected to drought happening once in a five year frequency. These areas are one of the most water stressed areas of the state as well as country. The mass migration tendencies seasonal as well as permanent towards Central and South Gujarat are observed regularly due to shortage of water, food and fodder. The main canal of Narmada dam has become a new source of water for this region.

\section{Narmada River and Narmada Basin}

The Narmada, the largest Westward flowing river, rises near the Amarkantak range of mountains in Madhya Pradesh. It is the fifth largest river in the country and the largest one in Gujarat. It traverses Madhya Pradesh, Maharashtra and Gujarat and meets the Gulf of Cambay. The total length of the river from source to sea is 1312 kilometres ( 815 miles) while the length up to the dam site is 1163 kilometres. (723 miles). The width of the river channel at the dam site during high floods is 488 meters (1600 feet) and, during summer, 45.70 meters (150 feet). The maximum recorded flood on 7th September 1994 was 70,847 cusecs ( 2.5 million cusecs) while the minimum recorded flow in summer was 8.5 cusecs (300 cusecs.) The dam is designed for 87,000 cusecs (3.07 million cusecs) flood. The total basin area of the river is 97,410 square kilometres comprising 85,858 square kilometres in Madhya Pradesh, 1658 square kilometres in Maharashtra and 9894 square kilometres in Gujarat. The drainage area up to dam site is 88,000 square kilometres [1]. 


\section{Sardar Sarovar Project}

The Sardar Sarovar Project is one of the largest water resources projects of India covering four major states - Maharashtra, Madhya Pradesh, Gujrat and Rajasthan. The dam's spillway discharging capacity (30.7 lakhs cusecs) would be the third highest in the world. With 1133 cumecs (40000 cusecs) capacity at the head regulator, and $532 \mathrm{~km}$. length, the Narmada Main Canal would be the largest irrigation canal in the world [1].

A concrete gravity dam, 1210 meters in length and with a maximum height of 163 meters above the deepest foundation level, is under construction across River Narmada. The dam will be the third highest concrete dam (163 meters) in India. In terms of the volume of concrete involved for gravity dams, this dam will be ranking as the second largest in the world with an aggregate volume of 6.82 million cu.m. The first is Grand Coule Dam in USA with a total volume of 8.0 million cu.m. This dam with its spillway discharging capacity of 87,000 cumecs (30.70 lac), will be the third in the world, Gazenba (1.13 lac cumecs) in China and Tucurri (1.0 lac cumecs) in Brazil being the first two. The gross storage capacity of the reservoir is $0.95 \mathrm{M}$. ha.m. (7.7 MAF) while the live storage capacity is $0.58 \mathrm{M}$.ha.m. (4.75 MAF). The dead storage capacity below minimum draw down level is $0.37 \mathrm{M}$. ha. m. (2.97 MAF). The construction of the dam up to 121.6 meters is over and construction of a $456 \mathrm{~km}$ long main canal is almost completed [1].

The reservoir would occupy an area of 37,000 ha. and would have a linear stretch of 214 kilometres of water and an average width of 1.77 kilometre. The Full Reservoir Level (FRL) of the Sardar Sarovar Dam is fixed at RL 138.68 meters (455 feet). The maximum water level is 140.21 meters (460 feet) while minimum draw down level is 110.64 meters (363 feet). The normal tail water level is 25.91 meters ( 85 feet) [1].

\section{Sardar Sarovar Canal based drinking water supply project}

The Sardar Sarovar Canal based drinking water pipeline project is perhaps the biggest drinking water project in the world. This project will cover Saurashtra, Kachchh as well as parts of North Gujarat (Ahmedabad, Mehsana, Banaskantha, Sabarkantha, and Panchmahal). Figure 2 shows the map of Gujarat depicting various areas of the state. The capital cost of the project has been estimated to be Rs. 103.7 billion (2010 prices), which includes investments in trunk mains, water treatment plants, pumping machinery, civil works and water distribution. The project includes 48 bulk schemes, 123 distribution groups and a 3,250 km long pipeline network. The project is extremely important for Gujarat, as it will cover 53.3 per cent of villages and 54 per cent of urban centres of the state. It will cover 100 per cent of villages in Ahmedabad, Amreli, Bhavnagar, Gandhinagar, Jamnagar, Junagadh, Kachchh, Porbandar and Surendranagar districts (Table 1). Similarly, all towns are proposed to be covered in Ahmedabad, Amreli, Bhavnagar, Jamnagar, Junagadh, Kachchh, Patan, Porbandar, Rajkot and 
Table 1: $\quad$ District wise coverage of villages/towns in revised master plan.

\begin{tabular}{|c|c|c|c|c|c|c|c|}
\hline \multirow[t]{2}{*}{ SI. No. } & \multirow[t]{2}{*}{ Districts } & \multirow{2}{*}{\begin{tabular}{|c|} 
Number \\
of villages \\
in the \\
district
\end{tabular}} & \multicolumn{2}{|c|}{$\begin{array}{l}\text { Villages covered in } \\
\text { the Master Plan }\end{array}$} & \multirow{2}{*}{$\begin{array}{c}\text { Number } \\
\text { of towns } \\
\text { in the } \\
\text { district }\end{array}$} & \multicolumn{2}{|c|}{$\begin{array}{l}\text { Towns covered in } \\
\text { the Master Plan }\end{array}$} \\
\hline & & & $\begin{array}{c}\begin{array}{c}\text { Number of } \\
\text { villages }\end{array} \\
\end{array}$ & $\begin{array}{l}\text { Percentage } \\
\text { of villages }\end{array}$ & & $\begin{array}{c}\text { Number of } \\
\text { towns }\end{array}$ & $\begin{array}{c}\text { Percentage } \\
\text { of towns }\end{array}$ \\
\hline 1 & Ahmedabad & 546 & 546 & 100 & 25 & 25 & 100 \\
\hline 2 & Amreli & 615 & 615 & 100 & 8 & 8 & 100 \\
\hline 3 & Anand & 350 & 0 & 0 & 12 & 0 & 0 \\
\hline 4 & Banaskantha & 1244 & 816 & 65.6 & 6 & 2 & 33.3 \\
\hline 5 & Bharuch & 657 & 0 & 0 & 8 & 0 & 0 \\
\hline 6 & Bhavnagar & 790 & 790 & 100 & 13 & 13 & 100 \\
\hline 7 & Dahod & 693 & 0 & 0 & 4 & 0 & 0 \\
\hline 8 & Dangs & 311 & 0 & 0 & 0 & 0 & 0 \\
\hline 9 & Gandhinagar & 291 & 291 & 100 & 10 & 4 & 40 \\
\hline 10 & Jamnagar & 698 & 698 & 100 & 16 & 16 & 100 \\
\hline 11 & Junagadh & 923 & 923 & 100 & 12 & 12 & 100 \\
\hline 12 & Kachchh & 886 & 886 & 100 & 8 & 8 & 100 \\
\hline 13 & Kheda & 612 & 65 & 10.6 & 8 & 0 & 0 \\
\hline 14 & Mehsana & 593 & 464 & 78.2 & 8 & 7 & 87.5 \\
\hline 15 & Narmada & 552 & 78 & 14.1 & 3 & 0 & 0 \\
\hline 16 & Navsari & 374 & 0 & 0 & 9 & 0 & 0 \\
\hline 17 & Panchmahal & 1201 & 408 & 34 & 6 & 3 & 50 \\
\hline 18 & Patan & 517 & 421 & 81.4 & 5 & 5 & 100 \\
\hline 19 & Porbander & 182 & 182 & 100 & 5 & 5 & 100 \\
\hline 20 & Rajkot & 844 & 844 & 100 & 10 & 10 & 100 \\
\hline 21 & Sabarkantha & 1372 & 956 & 69.7 & 8 & 6 & 75 \\
\hline 22 & Surat & 722 & 0 & 0 & 15 & 0 & 0 \\
\hline 23 & Tapi & 445 & 0 & 0 & 3 & 0 & 0 \\
\hline 24 & Surendranagar & 650 & 650 & 100 & 7 & 7 & 100 \\
\hline 25 & Vadodara & 1548 & 0 & 0 & 16 & 0 & 0 \\
\hline 26 & Valsad & 450 & 0 & 0 & 17 & 0 & 0 \\
\hline Total & & 18066 & 9633 & 53.3 & 242 & 131 & 54.1 \\
\hline
\end{tabular}

Surendranagar. In this project, water will be transported through bulk water transmission pipelines and distribution network to the doorsteps of villages and towns, which do not include in village/town drinking water supply infrastructure development. Thereafter, in rural areas Panchayats will take over the responsibility of distribution, management, operation and maintenance of in village water supply systems whereas local urban bodies will be responsible for distribution management, operation and maintenance in towns.

\section{Present status}

Though during its initial phase the project was quite slow in terms of implementation, by the end of October 2010 it has covered 6,513 of villages, i.e. about 68 per cent of villages against proposed coverage, and 114 towns i.e. about 87 per cent against the proposed coverage (Table.2). This is a commendable achievement. A $2,170 \mathrm{~km}$ pipeline has been laid (which is about $67 \%$ of the proposed 3,250 $\mathrm{km}$ pipeline). 


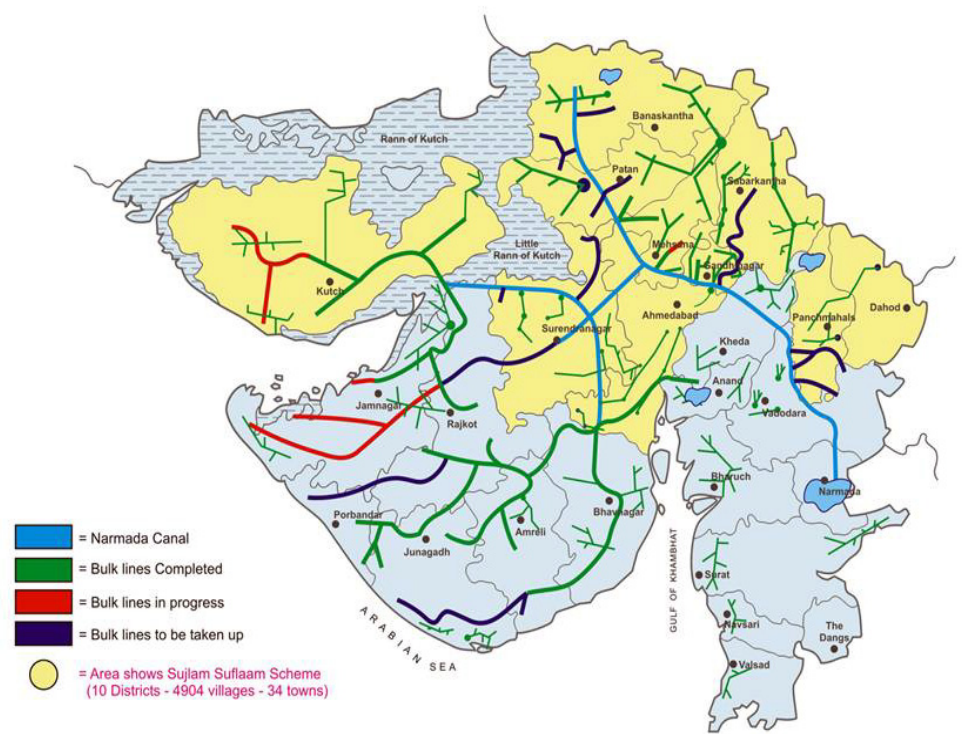

Figure 1: Bulk lines carrying Narmada canal water (source: nca.gov.in).

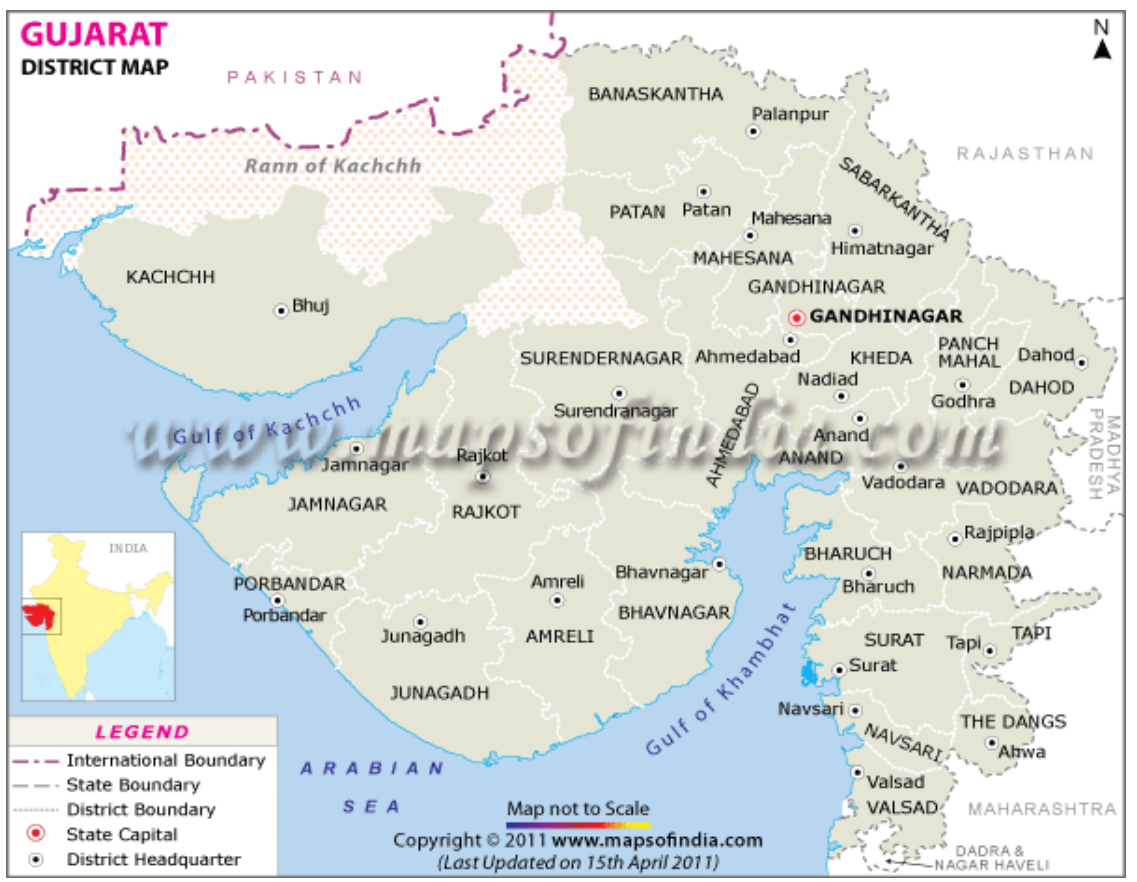

Figure 2: $\quad$ Map of Gujarat State. 
Table 2: $\quad$ Actual coverage of towns and villages till October 2010.

\begin{tabular}{|c|c|c|c|c|c|c|}
\hline District & $\begin{array}{c}\text { Number of } \\
\text { villages } \\
\text { to be covered } \\
\text { under } \\
\text { Narmada } \\
\text { water supply }\end{array}$ & $\begin{array}{c}\text { Number } \\
\text { of villages } \\
\text { already } \\
\text { covered }\end{array}$ & $\begin{array}{c}\text { Percentage } \\
\text { of villages } \\
\text { already } \\
\text { covered }\end{array}$ & $\begin{array}{c}\text { Number } \\
\text { of towns } \\
\text { to be } \\
\text { covered } \\
\text { under } \\
\text { Narmada } \\
\text { water } \\
\text { supply }\end{array}$ & $\begin{array}{c}\text { Number } \\
\text { of towns } \\
\text { already } \\
\text { covered }\end{array}$ & $\begin{array}{c}\text { Percentage } \\
\text { of towns } \\
\text { covered } \\
\text { under } \\
\text { Narmada } \\
\text { water } \\
\text { supply }\end{array}$ \\
\hline Ahmedabad & 546 & 508 & 93 & 25 & 25 & 100 \\
\hline Amreli & 615 & 456 & 74.1 & 8 & 8 & 100 \\
\hline Banaskantha & 816 & 454 & 56.6 & 2 & 2 & 100 \\
\hline Bhavnagar & 790 & 790 & 100 & 13 & 13 & 100 \\
\hline Gandhinagar & 291 & 291 & 100 & 4 & 4 & 100 \\
\hline Jamnagar & 698 & 668 & 95.7 & 16 & 16 & 100 \\
\hline Junagadh & 923 & 360 & 39 & 12 & 9 & 75 \\
\hline Kachchh & 886 & 743 & 83.9 & 8 & 8 & 100 \\
\hline Kheda & 65 & 65 & 100 & 0 & & \\
\hline Mehsana & 464 & 464 & 100 & 7 & 7 & 100 \\
\hline Narmada & 78 & 31 & 39.7 & 0 & & \\
\hline Panchmahal & 408 & 69 & 16.9 & 3 & 2 & 66.7 \\
\hline Patan & 421 & 348 & 82.7 & 5 & 5 & 100 \\
\hline Porbandar & 182 & 11 & 6 & 5 & 0 & 0 \\
\hline Rajkot & 844 & 541 & 64.1 & 10 & 6 & 60 \\
\hline Sabarkantha & 956 & 271 & 28.3 & 6 & 3 & 50 \\
\hline Surendranagar & 650 & 443 & 68.2 & 7 & 6 & 85.7 \\
\hline Total & $\mathbf{9 6 3 3}$ & $\mathbf{6 5 1 3}$ & $\mathbf{6 7 . 6}$ & $\mathbf{1 3 1}$ & $\mathbf{1 1 4}$ & $\mathbf{8 7}$ \\
\hline & & & & & & \\
\hline
\end{tabular}

\section{Issues and measures}

To make the Sardar Sarovar based drinking water supply project more sustainable it has to cope with challenges like reliability of supply, adequacy of supply, unequal inter village distribution, unequal intra village distribution, in efficiency in operation and maintenance, water charges, recovery of charges, neglected local source of water, lack of systematic disposal of used water, village level management and neglected local water sources.

\subsection{Unreliability of supply}

Villages covered under the Narmada project are expected to receive water every day. However in many villages water sometimes reaches once in two or three days. The officials blame unexpected power-cuts, failure of pumps and breakage of pipelines as major reasons for this. As a remedial measure they should have alternative plans to take care of such problems to strengthen the reliability of supply. 


\subsection{Inadequacy of supply}

Villages are expected to get water at the rate of $70 \mathrm{lpcd}$. In the absence of water meters, it is difficult to assess the adequacy of water supply. Based on population, supply varies from one hour per day to 3 hours per day but leakages in the pipeline result in low pressure and sometimes a 3 hour supply becomes equivalent to one hour to the end users. Therefore, it is suggested to install water meters at every village to assure quantum of supply and to check leakages in the pipeline through carrying out routine maintenance regularly.

\subsection{Unequal inter-village distribution}

It has not possible for authorities to provide equitable water supply to villages, because of frequent breakages and leakages in the inter-village pipelines. The technical problems such as weak joints, uneven pressure, design problems, poor maintenance of pipelines, failure of pumping machinery, electrically-failure, deliberate breakages and theft of water by farmers, cowherds and others. The suggested remedial measure towards this is ensuring proper design and maintenance of the pipeline. The involvement of people in the maintenance of pipe line is also an important measure to ensure inter village distribution.

\subsection{Unequal intra-village distribution}

Water will be provided at the doorsteps of villages and towns. It does not include drinking water supply infrastructure development for a village/town. While in urban areas many local bodies are able to manage distribution, in many villages it is observed that distribution to the streets within them is not equitable. In several villages, intra-village distribution of water is completely dominated by people from so called upper castes. This social barrier cannot be overlooked, when some villages are deprived of any other source of water supply. The co operative society be formed at the village level which can take care of in village water distribution. The member of the committees should be from all the streets of the village so that automatically supply to the streets be assured.

\subsection{Inefficiency in operation and maintenance}

The O\&M work has been entrusted to private contractors. They appoint linesmen to operate the valve, maintain the pipeline, clean the tank periodically, report breakages/leakages, manage repairs, observe the quality of water, apply chlorine if required, support the co operative society/village Panchayat in managing the water supply. However, it is observed that contractors are always keen to reduce their costs by understaffing (Hirway and Goswami [3]). Adequate supervision of the contractors by officials is needed to maintain smooth operation of lines.

\subsection{Water charges, recovery and financial viability}

Water charges under this project are meant to cover the O\&M costs and to provide for meeting the capital expenses for future replacement of the system. 
However, the status of recovery in the state has not encouraging. According to officials, current recovery varies between 25 to 35 per cent only. The status of recovery should also be viewed against the fact that the cost of Narmada water per unit is in fact much higher than what is charged to villagers. Therefore, even if cost subsidization is done to reduce the price, the present charges will fall tremendously short of the costs. The revision in the rates of water supply and increase in the recovery charges is recommended. Even some incentives may be given to the staffs who are involved in the recovery of charges.

\subsection{Neglected local sources of water supply}

Local sources are being badly neglected after water is available through Narmada pipeline project. The present approach discourages the survival and growth of local water sources (Sharma, 1995). Even villages suffering from serious shortages of water have neglected their own traditional tanks and wells. There is definitely a need to encourage conservation, augmentation and recharging of old water resources of the villages to meet the total demand.

\subsection{Absence of systematic disposal of used water}

Any amount of domestic water consumption ends with generation of waste water. In normal conditions for domestic water supply it is observed that about 80 per cent of the used water is discharged as waste water. Therefore any village with a population of 2,000 with 70 lpcd water supply will generate waste water amounting to 112,000 litres per day. However, management of waste water at the village level is not so efficient. It is a well established fact that proper disposal of waste water can reduce the incidence of waterborne diseases. The project should encourage better management of waste water at the village level in terms of its collection and systematic disposal with required treatment.

\subsection{Inefficient village level water management}

The state government has made the formation of water committees mandatory for all village Panchayats in the state. The Panchayat is supposed to form the committee by passing a resolution. Each committee will have 10-12 members, of whom one third will be women, 5 from the village Panchayat, 2-3 from locally registered NGOs (like local cooperatives, Women's federation, Farmer's society etc.) and 1-2 from SC/ST inhabitants. The water committees can play a vital role in the village level distribution and management of water and sanitation. The water committees will be capable of shouldering responsibilities like (1) taking care of water and sanitation management in the village (2) identifying local water sources and preparing a scheme for their development and implementation, (3) managing the water sources of the village (4) carrying out O\&M of the regional scheme if local sources are not available (5) taking care of sanitation and cleanliness of the village (6) assuring equal distribution of water in the village and (7) fixing and collecting water charges from people. 


\section{Conclusion}

It is evident from the study that Sardar Sarovar Canal based drinking water project in Gujarat is of immense importance. The state has been suffering from chronic problem of drinking water supply since 1960s. Over time, with increasing demand for drinking water, the concerns become more critical. Like any other long distance pipeline scheme under which water is transported through pipelines, this project also have several built-in weaknesses, which arise from the project concept and design on the one hand and the socio-cultural and administrative capabilities in the state on the other. Overcoming these weaknesses should be a major concern of policy makers and implementers at present, to achieve the long term sustainability of the project.

\section{References}

[1] A. Bhattacharya (2007), Report on "Drinking Water Supply Schemes", Department of Drinking Water Supply, Ministry of Rural Development, India.

[2] Gujarat water supply sewerage board (2010), Narmada Canal Based Projects, Progress Report.

[3] Hirway, Subhrangsu Goswami, (2008), Dynamics of Crisis in Drinking Water in Coastal Gujarat with Special Reference to Saurashtra Coast, Working Sample paper, CFDA, Ahemedabad

[4] Jay Narayan Vyas (2011), Sardar Sarovar Project: The Engineering Marvel, Sardar Sarovar Project on the Narmada, Vol. 1, Concept Publishing Company Pvt. Ltd., New Delhi -59

[5] P. Parthsarathy, Ravindra Dholakiya (2011), Sardar Sarovar Project: Performance so far, plans and opportunities, Sardar Sarovar Project on the Narmada, Vol. 3, Concept Publishing Company Pvt. Ltd., New Delhi -59

[6] P. Parthsarathy , Ravindra Dholakiya (2011), Sardar Sarovar Project: Background and Overview, Sardar Sarovar Project on the Narmada, Vol. 1, Concept Publishing Company Pvt. Ltd., New Delhi -59

[7] Meera Mehta, Dinesh Mehta (2011),Urban drinking water security and

[8] sustainability in Gujarat, India, Sardar Sarovar Project on the Narmada, Vol. 3,Concept Publishing Company Pvt. Ltd., New Delhi -59

[9] Shah, T.; Krishnan, S.; Hemant, P.; Verma, S.; Chandra, A.; Sudhir, C. 2010. A case for pipelining water distribution in the Narmada Irrigation System in Gujarat, India. Colombo, Sri Lanka: International Water Management Institute. 25p.

[10] Talati, J.; Liebrand, J.; 2003, Evolving institutions for irrigation management in Sardar Sarovar Project command, IWMITata Water Policy Program, Anand, India.

[11] Narmada Control Authority, www.nca.gov.in

[12] SSNL, www.sardarsarovardam.org. 